\title{
An application of the American customer satisfaction index (ACSI) in the South African motor vehicle industry
}

\author{
N.S. Terblanche* \\ Department of Business Management, University of Stellenbosch \\ Stellenbosch 7600, Republic of South Africa \\ nst@maties.sun.ac.za
}

Received August 2006

\begin{abstract}
Longer relationships with customers, with an anticipated concomitant increase in profitability flowing from such relationships, have become the focus of many businesses. Over time numerous measures to gauge and predict loyalty and commitment have been developed with the purpose to assist management in this respect. However, one of management's major challenges is to employ a model that is appropriate to explain and predict customer retention for a particular company or brand. This study investigates the reliability of the ACSI for South Africa and reports on the empirical findings in respect of the relationships between various dimensions in the ACSI model as applied in the South African motor vehicle industry. Apart from a paper in press, no research or application of the ACSI has been published in any South African academic journal (Terblanche, 2006). The motor vehicle industry as a whole as well as two individual motor vehicle brands is the focal point of this study. The strengths of various relationships such as, for instance, the relationship between customer satisfaction and customer loyalty and the relationship between customer expectations and perceived value were studied. The interpretations of the findings between the various dimensions, which are useful from both a theoretical and a managerial perspective, are offered.
\end{abstract}

*To whom all correspondence should be addressed.

\section{Background}

Customer retention has become so important for businesses that some author's even label is as 'the Holy Grail in industries from airlines to wireless' (Coyles \& Gokey, 2005). In numerous studies customer retention was identified as a significant contributor to profitability over the long term (Anderson \& Sullivan, 1993; Fornell, 1992; Iniesta \& Sánchez, 2002; Heskett, Sasser \& Schlesinger, 1997; Heskett, 2002; Dick \& Basu, 1994; Anderson, Fornell \& Lehmann, 1994). What constitutes the best measure of customer retention is still open for deliberation. However, satisfaction, loyalty and commitment, have received the most exposure as measures of customer retention in academic journals the past fifteen years (Oliver, 1999; Auh \& Johnson, 2005; Wetzels, De Ruyter \& Van Birgelen, 1998). The relationships between satisfaction and loyalty and between satisfaction and commitment have, on the whole, received the major share of attention in the academic literature (Oliver, 1999; Clerfeuille \& Poubanne, 2003). Various authors have also conceptualised and operationalised customer retention as a dimension of the loyalty construct (Boulding, Kolra, Staelin \& Zeithaml, 1993; Zeithaml, Berry \& Parasuraman, 1996).

\section{Introduction}

The 1980's experienced various endeavours to enhance the consistency and quality of goods and services produced. All these attempts culminated in what became known as the total quality movement (TQM). TQM, despite its promising virtues, faded away as a management approach because of its inability to improve either economic returns or competitiveness. The search for alternative means to increase profitability then started to focus on the assumption that providing high-quality goods and services to the market have an effect on profitability through customer satisfaction (Anderson et al., 1994: 53-54; Forza \& Filippini, 1998; Choi \& Eboch, 1998). Research on quality improvements and enhanced satisfaction to increase profitability eventually led to the development of national customer satisfaction indices. These indices relied on customer experiences and perceptions to measure the performance of firms, industries and economic sectors (Fornell, Johnson, Anderson, Cha \& Bryant, 1996:7). The first national customer satisfaction index that was published was the Swedish Customer Satisfaction Barometer (Fornell, 1992). The first ACSI model was an adaptation of the Swedish Customer Satisfaction Barometer. ACSI was subjected to tests in 1993 and introduced in 1994, initially covering 7 sectors, 30 industries and over 180 companies (ACSI, 2001:2).

Various national measures of customer satisfaction, derived from the ACSI methodology, were developed in countries such as Norway (Andreassen \& Lindestad, 1998a and 1998b; Andreassen \& Lervik, 1999), Denmark (Martensen, Grønholdt \& Kristensen, 2000), Europe (ECSI Technical Committee, 1998; Eklöf, 2000) and Austria (Hackl, Scharitzer \& Zaba, 1996). With the extended application of national measures of customer satisfaction, researchers also started to expose weaknesses in ACSI. The major criticism levelled at ACSI was the weak linkages between customer 
expectations and the other dimensions as well as the items used to measure customer loyalty.

The customer satisfaction models applied in the countries other than the USA, such as Europe for instance, also differ from the latest ACSI version (see Figure 1) in that an image variable was added. In the European model image is treated as an antecedent of both perceived value and customer loyalty. Whereas ACSI use price tolerance and intention to repurchase to measure customer loyalty, the European model makes use of three items to measure customer loyalty. These three items are the customer's intention to repurchase, intention of cross buying and intention to recommend the brand/company to other consumers (Juhl, Kristensen \& Østergaard, 2002: 328). The latest customer satisfaction index to be developed is the European Performance Satisfaction Index (EPSI). Twelve countries, namely the Czech Republic, Denmark, Estonia, Finland, Greece, Iceland, Latvia, Lithuania, Norway, Portugal, Russia and Sweden, were surveyed in 2005 (EPSI Rating, 2006).

\section{Purpose of the article}

In 2005 the ACSI methodology was used in a study of the fast food and motor vehicle industries in South Africa. The fast food and motor vehicle industries were selected because both are highly competitive whilst their products represent the two extremes of low involvement products (fast food) and high involvement products (motor vehicles). This article deals with the results in respect of the motor vehicle industry. Very little research has been published on brand loyalty of motor vehicles since the work of Mannering and Winston on brand loyalty of American motor vehicles was published in 1991.

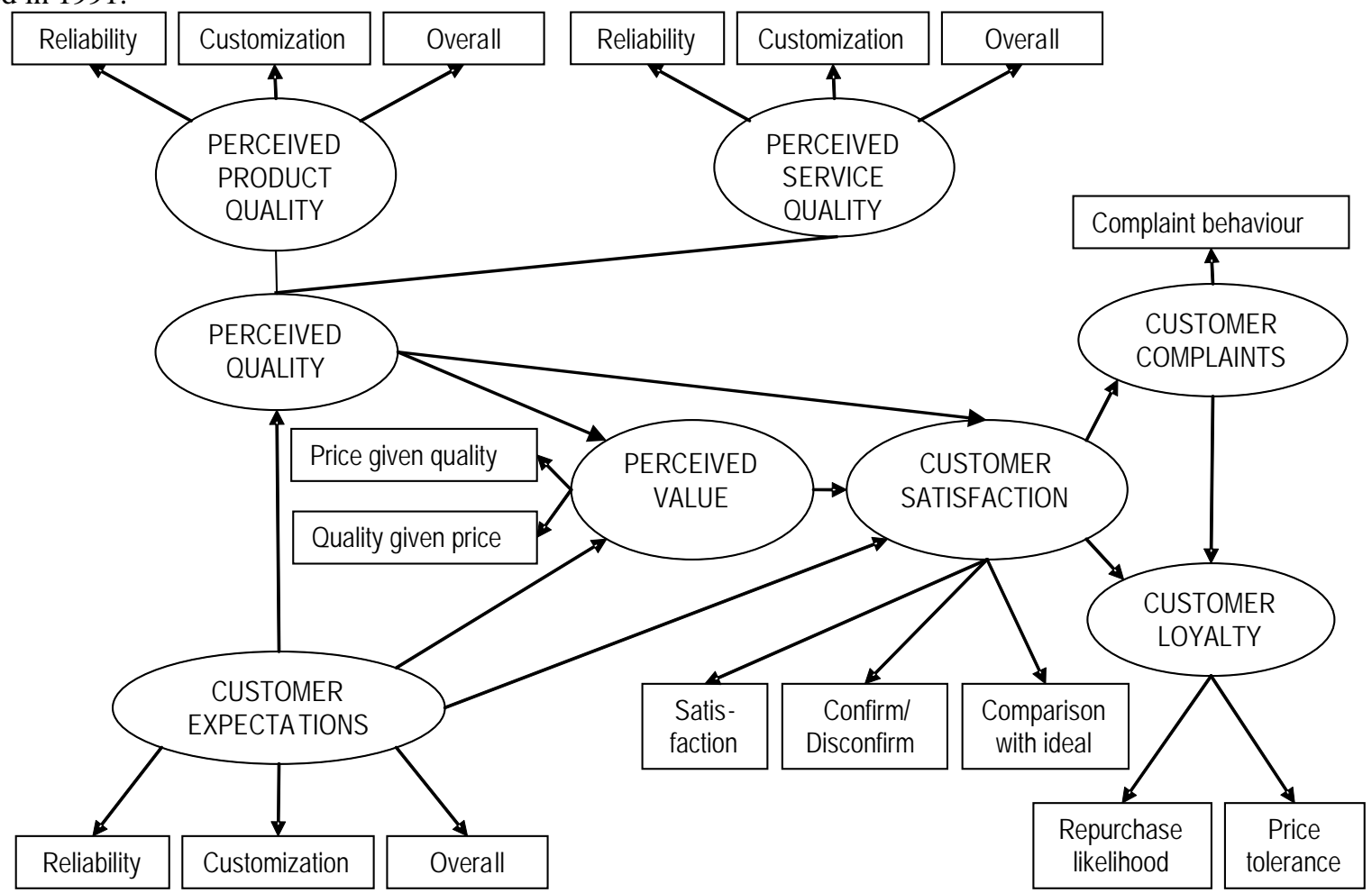

The purpose of this study was to investigate the reliability of the ACSI for the South African motor vehicle industry. The primary research objective of the study was to report on the empirical findings in respect of the relationship between customer satisfaction and customer loyalty in the ACSI model for the motor vehicle industry in South Africa. The secondary research objective of the study was to report on the empirical findings in respect of the relationships between the other dimensions (customer expectations, overall product quality and perceived value) in the ACSI model for the motor vehicle industry in South Africa.

\section{The theoretical framework of ACSI}

A primary objective of ACSI is to estimate the effect of satisfaction on customer loyalty; customer loyalty is the ultimate dependent variable in the ACSI model because of its value as a substitute for customer retention and its effect on profitability (American Customer Satisfaction Index, 2001; Fornell, et al., 1996; Johnson, Gustafson, Andreasen, Lervik \& Cha, 2001).

The initial ACSI model of 1994 customer satisfaction had three antecedents. These antecedents were perceived quality, perceived value and customer expectations (Johnson et al., 2001:222). The ACSI model was expanded in 1996 to make provision for two types of perceived quality, namely product (physical good) quality and service quality. These changes were essential to provide for manufacturing durables that contain both a large product and a large service component (Johnson, et al., 2001: 223). Figure 1 is a graphical illustration of the latest version of ACSI. 
Customer satisfaction is the focal point in a chain of relationships in ACSI. These relationships extend from the antecedents of customer satisfaction (perceived quality, perceived value and customer expectations) to the consequences of customer satisfaction (complaints and loyalty) (Fornell, et al., 1996:8). Satisfaction in the ACSI model means cumulative satisfaction and it is defined as a customer's overall experience to date with a product or service provider (Johnson \& Fornell, 1991). In a study by Olsen and Johnson (2003: 193-194) it was found that the variation explained in loyalty increased from 35\% and 34\% for transaction-specific samples to $45 \%$ and $63 \%$ for cumulative samples. Cumulative satisfaction also holds an essential advantage over a more transaction exclusive view, in the sense that it is better capable to forecast future behaviour and economic performance (Fornell, et al., 1996; Johnson, Anderson and Fornell (1995).

Customer satisfaction has been credited with many worthwhile consequences. Fornell, Mithas, Morgeson, and Krishon (2006:4) mention published research which found a positive relationship between customer satisfaction and loyalty, usage behaviour, reduced cost of future transactions, reduced costs related to warranties, complaints, defective goods and field service costs. The focus in this study is on the relationship between customer satisfaction and customer loyalty. Based on the preceding discussion, the following proposition is suggested:

P1: There is a positive relationship between customer satisfaction and customer loyalty in the South African motor vehicle industry

\section{Antecedents of customer satisfaction in ACSI}

Customer satisfaction has three antecedents, namely perceived quality, perceived value and customer expectations in the ACSI.

\section{Perceived quality}

Customers' view of perceived quality is the culmination of how they experience product performance. Product performance can be defined as the degree of customisation and freedom from deficiencies, or how reliably the product meets its specifications (Johnson \& Ettlie, 2001:194). It was found that reliability is relatively more important for service satisfaction than product satisfaction (Johnson \& Nilsson, 2000). In the ACSI model reliability is regarded as equally important in product and service satisfaction. The causal order of perceived quality and customer satisfaction has been a source of debate amongst researchers (Dabholkar, Shepherd \& Thorpe, 2000). The conflicting results created by inconsistencies in the definition and measurement of quality and customer satisfaction have also led to diverse findings in respect of the relationships between quality and satisfaction (Choi \& Eboch, 1998; Hardie, 1998; Sousa \& Voss, 2002). Research now supports the view that satisfaction is the behavioural consequence of perceived quality (Green \& Boshoff, 2002:12; Gallarza \& Saura, 2006:448). The ACSI model assumes that an increase in perceived quality leads to a concomitant increase in the level of customer satisfaction (American Customer Satisfaction
Index, 2001:12). This assumption subscribes to the theoretical perspective which states that customer satisfaction results from consumers' favourable evaluations of the quality of goods and services (Babakus, Bienstock \& Van Scotter, 2004:718; Liu, 2005:433). Based on the research findings that satisfaction is the behavioural outcome of quality, the following proposition is suggested:

P2: There is a positive relationship between perceived product quality and customer satisfaction in the South African motor vehicle industry

Perceived quality (the composite of product (physical good) quality and service quality) is modelled in the ACSI to have an effect on perceived value. Researchers also found that perceived quality had a significant effect on perceived value (Dodds, Monroe \& Grewal, 1991). Another study found that product value was enhanced by marketing communications that promote quality (Rangaswamy, Burke \& Oliva, 19930. Ostrom and Iacobucci (1995) established that quality had a significant influence on perceived service value under dissimilar conditions. It can thus be concluded that prior research concurs that perceived quality identified at the time of purchase influence perceived value. Based on the support for the influence of perceived quality on perceived value, the following proposition is suggested:

P3: There is a positive relationship between perceived quality and perceived value in the South African motor vehicle industry

\section{Perceived value}

A research approach in which consumer behaviour is better comprehended when explored through perceived value, has been prevalent since the nineties (Nilson, 1992; Ostrom and Iacobucci, 1995; Jensen, 1996; Woodruff \& Gardial, 1996; Heskett, et al., 1997). The value concept has been described as 'multi faceted and complex' because the term 'value is extremely abstract and polysemous in nature' (Gallarza \& Saura, 2006:438). MacKay (1999:182) highlighted the importance of utilitarian and hedonic components of perceived value by stating that a product's or service's appeal is an 'amalgam of rational and emotional factors'. Later on Sweeney and Soutar (2001:216) developed a fourdimensional scale for the value construct which include both utilitarian and hedonic components. Consumers, researchers as well as practitioners have assigned different meanings to value (Zeithaml, 1988; Lai, 1995; Woodruff \& Gardial, 1996). Value has also been called an amorphous concept by Zeithaml and Bitner (1996:3). Lin, Sher and Shih (2005:333) suggested that perceived value should be defined as a second-order multi-dimensional formative construct. In their study Lin, et al. (2005) identified five constructs (monetary sacrifice, web site design, fulfilment/reliability, security/privacy and customer service) to underlie perceived value.

Various studies that have drawn on research in different fields support the view that customer value may go further than the price-quality trade-off (Kumar \& Grisaffe, 2004:46). In 1996 Holbrook proposed a typology of customer value using a framework derived from the philosophical field of axiology (theory of value). According 
to Holbrook eight different types of customer value, namely excellence (quality), efficiency (convenience), status (success), esteem (reputation), play (fun), aesthetics (beauty), ethics (virtue/morality) and spirituality (faith) exist. Holbrook's value types refer, without exception, to what a customer can 'get' from a product or service. Zeithaml (1988) differ with Holbrook's types and conceptualise value as having both a 'get' and a 'give' element. The significance of perceived value in marketing is exemplified by the views of several authors who are of the opinion that perceived value will increase in importance in this century (Woodruff, 1997; Forester, 1999; Treadgold, 1999:45). The ACSI model defines perceived value as the perceived level of product or service quality relative to the price paid (Fornell et al., 1996:9; American Customer Satisfaction Index, 2001:12). The preceding discussion leads to the following proposition:

P4: There is a positive relationship between perceived value and customer satisfaction in the South African motor vehicle industry

\section{Customer expectations}

Customer expectations sum up a customer's prior consumption experience with a firm's products or services as well as marketing communication and word-of-mouth information (Johnson, et al., 2001: 221). Expectations are regarded as appropriate to forecast a firm's ability to provide future performance and as such should have a positive influence on customer satisfaction (Fornell, 1992; ACSI, 2001). It is important that marketers understand customer expectations, because different expectations enable marketers to identify different market segments. The latter enable marketers to develop distinct strategies for different market segments (Webster, 1989; Pitt, Oosthuizen \& Morris, 1992). A wide range of factors create customer expectations. A customer's previous experiences, the communication of an organisation with its customers, advertisements, service recovery, promises, informal recommendations, formal recommendations, price to be paid, personal needs, corporate image and salespeople all influence the formation of customer expectations (Zeithaml, Parasuraman \& Berry, 1990; Pitt \& Jeantrout, 1994; Hart, Heskett \& Sasser, 1996; Zeithaml, Berry and Parasuraman, 1993; Robledo, 2001; Teboul, 1991; Grönroos, 1984, 1990; Cadotte, Woodruff \& Jenkins, 1987; Yu, 2005; Bebko, 2000).

The ACSI model defines customer expectations as the level of quality that customers expect to receive and as such serves as the benchmark that is adjusted or updated in accordance with a customer's more recent purchase and consumption experience or what has been communicated to him or her about the product or service. This view is similar to the predicted service level of expectations as suggested by Zeithaml, Berry and Parasuraman (1993). In the ACSI model customer expectations are deemed to be positively related to customer satisfaction, perceived value and perceived quality (ACSI, 2001). Based on the findings in respect customer expectations, the following three propositions are investigated in this study:
P5: There is a positive relationship between customer expectations and customer satisfaction in the South African motor vehicle industry

P6: There is a positive relationship between customer expectations and perceived value in the South African motor vehicle industry

P7: There is a positive relationship between customer expectations and perceived quality in the South African motor vehicle industry

\section{Measures}

The scales used in this study, are those set out in the ACSI methodology report (American Customer Satisfaction Index, 2001). The latent variables (dimensions) and the manifest variables (items) used to measure the latent variables are set out in Table 1.

The dimensions measured were customer expectations, perceived product quality, perceived service quality, perceived value, customer satisfaction, customer complaints and customer loyalty. Most of the dimensions (except for customer complaints and perceived value) were measured with three items. The items were linked to a 10 point semantic differential scale, ranging from not very high/not very well/very often/almost never/only some/very poor/very dissatisfied/ etc (1) to very high/well/not very often/almost always/all/very good/very satisfied/ etc (10). Customer complaints were measured by whether a respondent complained in the past 6 months (Yes/No) and how well the complaint was handled - on a 10 point Likert scale ranging from handled very poorly (1) to handled very well (10). Perceived value was measured with two items on a 10 point semantic differential scale.

\section{Data collection}

A structured questionnaire was used to collect data and it was administered by means of personal interviews. Interviews were conducted with respondents during June 2005. To ensure a representative sample, respondents were drawn randomly per suburb. Suburbs were drawn from the 2001 South African census and five interviews were conducted within each selected suburb to ensure that a demographically representative sample was obtained across suburbs and areas. The total sample for this study was 2000 interviews. Other characteristics of the sample and sampling procedure are as follows:

- the interviews were conducted in the seven major metropolitan areas of South Africa

- the sample is in the same proportions of the South African population in terms of both ethnic group and gender to be representative

- $\quad$ respondents were interviewed in-home

- $\quad$ respondents were required to be 18 years and older to qualify for the interview. 
Table 1: Latent and manifest variables of ACSI

\begin{tabular}{l|l}
\hline \multicolumn{1}{c|}{ Latent Variables } & \multicolumn{1}{c}{ Manifest Variables(Items) } \\
\hline Customer expectations & $\begin{array}{l}\text { Overall expectation of quality (pre-purchase) } \\
\text { Expectation regarding customization, or how well the product and } \\
\text { service fits the customer's personal requirements (pre-purchase) } \\
\text { Expectation regarding reliability, or how often things would go } \\
\text { wrong (pre-purchase) }\end{array}$ \\
\hline Perceived product quality & $\begin{array}{l}\text { Overall evaluation of quality experience with product (post- } \\
\text { purchase) } \\
\text { Evaluation of customization experience, or how well the product fits } \\
\text { the customer's personal requirements (post-purchase) } \\
\text { Evaluation of reliability experience, or how often things have gone } \\
\text { wrong with product (post-purchase) }\end{array}$ \\
\hline Perceived service quality & $\begin{array}{l}\text { Overall evaluation of quality experience with service (post-purchase) } \\
\text { Evaluation of customization experience, or how well the service fits } \\
\text { the customer's personal requirements (post-purchase) } \\
\text { Evaluation of reliability experience, or how often things have gone } \\
\text { wrong with service (post-purchase) }\end{array}$
\end{tabular}

Source: American Customer Satisfaction Index, 2001:14

A total of 34 motor vehicle brands were included in the survey. For the purposes of this study, only the two most owned motor vehicle brands are analysed. The reason for the latter decision is that the rest of the motor vehicle brands have very limited ownership amongst the respondents.

\section{Data analysis}

The relationships in the ACSI model were estimated with Partial Least Squares (PLS). PLS is an iterative estimation procedure that integrates aspects of principal-components analysis with multiple regressions and is regarded as suitable to predict the relationships in the ACSI model (Gustaffson \& Johnson, 1997; Steenkamp \& Van Trijp, 1996; Wold, 1982). Earlier research also indicates that PLS is appropriate for explaining complex relationships and to predict empirical and or theoretical variables (Fornell \& Bookstein, 1982). PLS requires each variable to be measured by using interval scale measures and therefore each latent variable indicator in this study was measured using semantic differential items as explained in the earlier paragraph on measures. The customer complaint dimension was not included in estimation calculations because an insignificant number of respondents reported that they have complained within the required period.

\section{Results}

The primary objective of this study was to consider the reliability of the ACSI for the South African motor vehicle industry. Secondary purposes were to assess the strengths of the relationships between various dimensions in the ACSI model for motor vehicle brands in South Africa.

The motor vehicle industry as a whole as well as two individual motor vehicle brands was the focal point of this study. The major relationship investigated was the prediction of customer loyalty by ACSI, where customer loyalty is based on customer satisfaction and customer satisfaction is the outcome of customer expectations, overall product quality and product value. As can be seen from Figure 2 and Table 2, the results for the motor vehicle industry indicate that $36,8 \%$ (from $\mathrm{R}^{2}$ ) of the variance in customer loyalty is explained by customer satisfaction. The balance, $63 \%$, can be ascribed to measurement errors in customer satisfaction and loyalty, together with the influence of other unknown factors.

Table 3 contains the $\mathrm{R}^{2}$ values for the two individual motor vehicle brands. These values are $39,8 \%$ for Toyota and $33,3 \%$ for Volkswagen. What an ideal $\mathrm{R}^{2}$ for a motor vehicle brand should be, is arguable. The amount of variance in loyalty explained by a single factor such as satisfaction can be regarded as meaningful. Satisfaction thus seems important for the formation of customer loyalty in the motor vehicle industry.

Composite reliability values were calculated to determine how well loyalty is measured by the items used to measure loyalty. The composite reliability indicated a value of 0,508 for customer loyalty in the motor vehicle industry as a whole and is lower than that of any of the other latent variables. The two items used for the measurement of loyalty consistently produced contradictory findings. The item measuring the intention to purchase the respondent's favourite motor vehicle brand again in the future consistently produced positive results. The items that are combined to measure the respondent's continual support if prices are increased or lowered, produced conflicting results, indicating that these particular two items are not suitable for measuring loyalty. 


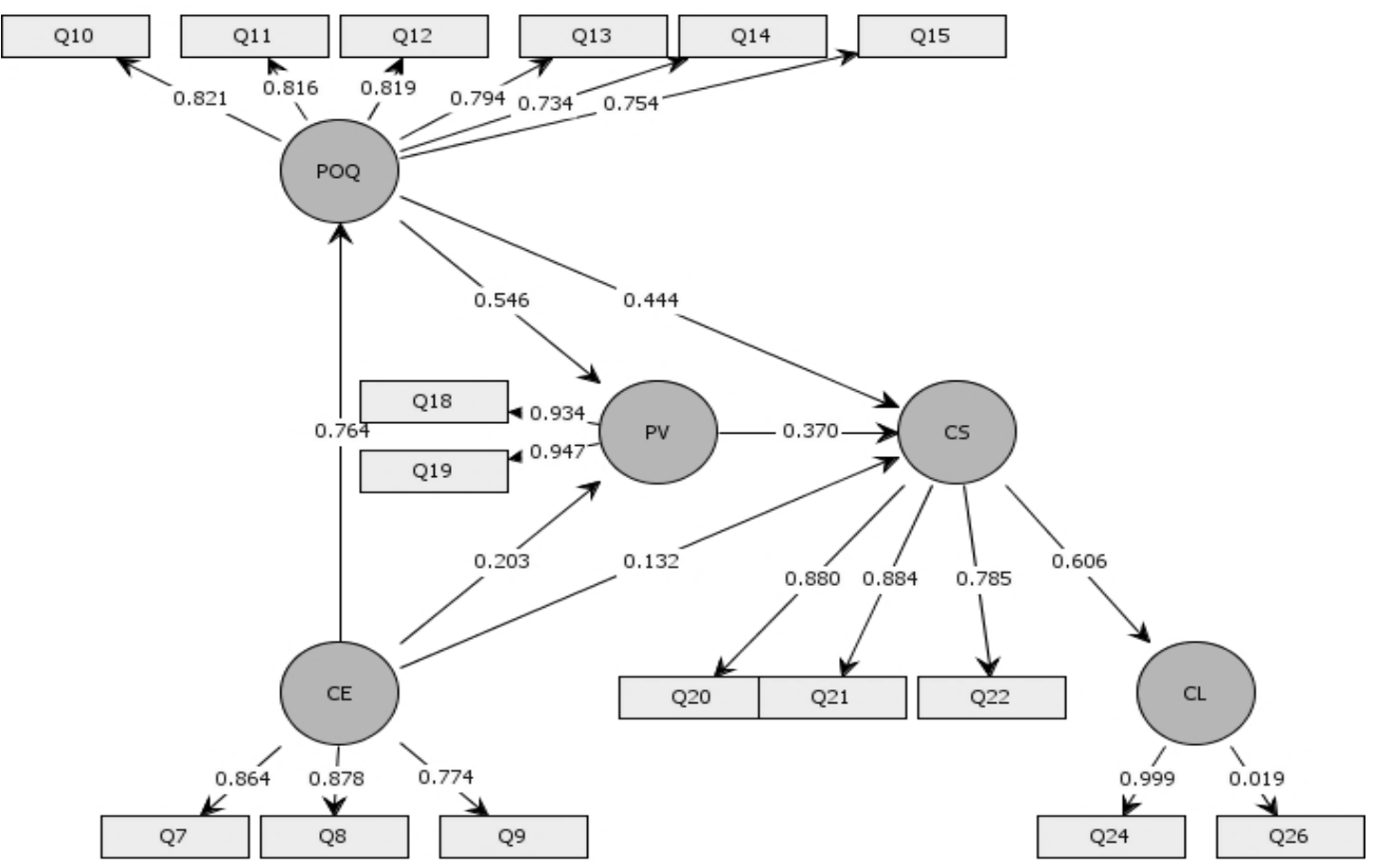

Figure 2: Expanded ACSI model for the motor vehicle industry

Table 2: Variance explained and composite reliability of the motor vehicle industry

\begin{tabular}{l|c|c}
\hline & $\mathbf{R}^{2}$ & Composite Reliability \\
\hline Product overall quality(POQ) & $\mathbf{0 , 5 8 4}$ & $\mathbf{0 , 9 0 9}$ \\
\hline Customer expectations(CE) & & $\mathbf{0 , 8 7 8}$ \\
\hline Perceived value(PV) & $\mathbf{0 , 5 0 9}$ & $\mathbf{0 , 9 3 9}$ \\
\hline Customer satisfaction(CS) & $\mathbf{0 , 7 3 2}$ & $\mathbf{0 , 8 8 7}$ \\
\hline Customer loyalty(CL) & $\mathbf{0 , 3 6 8}$ & $\mathbf{0 , 5 0 8}$ \\
\hline
\end{tabular}

Table 3: Variance explained and composite reliability of the individual motor vehicle brands

\begin{tabular}{l|c|c|c|c|c|c|c|c|c}
\hline & \multicolumn{4}{|c|}{$\mathbf{R}^{2}$} & \multicolumn{4}{c}{ Composite reliability } \\
\cline { 2 - 10 } & POQ & PV & CS & CL & POQ & CE & PV & CS & CL \\
\hline Toyota & 0,461 & 0,370 & 0,690 & 0,398 & 0,888 & 0,838 & 0,920 & 0,841 & 0,665 \\
\hline Volkswagen & 0,679 & 0,531 & 0,722 & 0,333 & 0,913 & 0,924 & 0,939 & 0,849 & 0,530 \\
\hline
\end{tabular}

Figure 2 demonstrates that all the relationships between the different dimensions are in the direction predicted in the propositions. Not all the relationships are, however, strong. The relationships between customer satisfaction and customer loyalty, customer expectations and perceived quality as well as perceived quality and perceived value are rather strong. The relationships between perceived quality and customer satisfaction and perceived value and customer satisfaction can probably be be described as moderate. Even though the relationship between customer expectations and perceived quality are the strongest in this study, the relationships between customer expectations and other dimensions vary. As a matter of fact, the relationships between customer expectations and perceived value and customer expectations and customer satisfaction are very weak. Johnson, et al. (2001:227-228) provides quite a thorough discussion of some of the relationships involving the antecedents and consequences of satisfaction in the ACSI which are conceptually and/or empirically weak. It is especially the weak linkages between customer expectations and the other dimensions, as again confirmed in this study, that have been criticised heavily. This founding urged Johnson, et al. (2001: 228-229) to suggest the elimination of customer expectations as a construct when cumulative satisfaction measures are used and their suggestion is supported with examples from various industries. 


\section{Managerial implications}

This study's findings are useful from both a theoretical and a managerial perspective. Customer satisfaction which drives customer loyalty in the ACSI model seems to be a good predictor of customer loyalty in the South African motor vehicle industry. The items used to measure customer loyalty demonstrated a weakness because it scored low on reliability. Items such as intention to recommend and intention to purchase the particular motor vehicle brand again in the future have been used extensively in various studies to measure loyalty. The use of such items in the place of the item that produced a negative relationship with loyalty, could improve the composite reliability of the items used to measure loyalty.

The findings of the study are supportive of the views of authors that endorse a positive relationship between satisfaction and loyalty. At the same time the findings are in conflict with the views of various authors who state that customer satisfaction cannot be a sole predictor of customer loyalty. Different items might also improve such measurement. The latter point was raised by a prominent researcher who has applied the ACSI in many studies (Johnson, 2003). Thus, not all satisfaction (even at a high degree) translates into loyalty (Mittal \& Lassar, 1998). Andreassen and Lindestad (1998) also found that, contrary to their expectations, customer satisfaction has no impact on customer loyalty. It has also been proposed that trust is a stronger emotion than satisfaction and it may therefore better predict retention (Hart \& Johnson, 1999).

Managers are continually confronted with the dilemma that, even when their customers say they're satisfied, they still switch to other brands. Reality is that satisfied customers aren't necessarily or don't inevitably become loyal customers. Loyalty as such, demands a commitment from the customer that sheer satisfaction cannot bring. The implications for managers are that customer satisfaction measures are inadequate on their own and need supplementing by a measure of loyalty. In other words, it means that one cannot focus only on those elements of quality creating satisfaction because such elements don't necessarily convert into loyalty.

\section{Limitations of the study}

Care should be exercised in the interpretation and utilisation of the results. The major reason for this is that, although the sample is representative of the entire South African population, this does not necessarily mean that the respondents are representative of typical motor vehicle owners. In other words, the typical owners of the various motor vehicle brands might be underrepresented in the sample.

\section{References}

American Customer Satisfaction Index, 2001. Methodology report. Ann Arbor, MI: The Regents of the University of Michigan.
Anderson, E. W., Fornell, C. \& Lehmann, D. R. 1994. 'Customer satisfaction, market share, and profitability: Findings from Sweden', Journal of Marketing, 58(3): 53-66.

Anderson, E.W. \& Sullivan, M.W. 1993. 'The antecedents and consequences of customer satisfaction for firms', Marketing Science, 12(2): 125-43.

Andreassen, T.W. \& Lindestad, B. 1998. 'Customer loyalty and complex services', International Journal of Service Industry Management, 9(1): 7-23.

Andreassen, T.W. \& Lindestad, B. 1998a. 'The effects of corporate image in the formation of customer loyalty', Journal of Service Marketing, 1(1): 82-92.

Andreassen, T.W. \& Lindestad, B. 1998b. 'Customer loyalty and complex services: The impact of corporate image on quality, customer satisfaction and loyalty for customers with varying degrees of service expertise', International Journal of Service Industry Management, 9(1): 7-23.

Auh, S. \& Johnson, M.D. 2005. 'Compatibility effects in evaluations of satisfaction and loyalty', Journal of Economic Psychology, 26(1): 35-57.

Babakus, E., Bienstock, C.C. \& Van Scotter, J.R. 2004. 'Linking perceived quality and customer satisfaction to store traffic and revenue growth’, Decision Sciences, 35(4): 713737.

Bebko, C.P. 2000. 'Service intangibility and its impact on consumer expectations of service quality', Journal of Services Marketing, 14(1): 9-26.

Boulding, W., Kalra, A., Staelin, R. \& Zeithaml, V. A. 1993. 'A dynamic process model of service quality: From expectations to behavioral intentions' Journal of Marketing Research, 30(1): 7-21.

Cadotte, E.R., Woodruff, R.B. \& Jenkins, R.L. 1987. 'Expectations and norms in models of consumer satisfaction', Journal of Marketing Research, 24(3): 305314.

Choi, T.Y. \& Eboch, K. 1998. 'The TQM paradox: Relations among TQM practices, plant performance, and customer satisfaction', Journal of Operations Management, 17(1): 59-75.

Clerfeuille, F. \& Poubanne, Y. 2003. 'Differences in the contributions of elements of service to satisfaction, commitment and consumers' share of purchase: A study from the tetraclass model', Journal of Targeting, Measurement and Analysis for Marketing, 12(1): 66-81.

Coyles, S. \& Gokey, T.C. 2005. 'Customer retention is not enough’, Journal of Consumer Marketing, 22(2): 101-105.

Dabhalkor, P.A., Shepherd, C.D. \& Thorpe, D.I. 2000. 'A comprehensive framework for service quality: An investigation of critical conceptual and measurement issues 
through a longitudinal study', Journal of Retailing, 76(2): 139-173.

Dick, A. S. \& Basu, K. 1994. 'Customer loyalty: Towards an integrated framework', Journal of the Academy of Marketing Science, 22(2): 99-113.

Dodds, W. B., Monroe K. B. \& Grewal, D. 1991. 'Effects of price, brand and store information on buyers' product evaluations', Journal of Marketing Research, 28(3): 307319.

ECSI Technical Committee. 1998. European customer satisfaction index, foundation and structure for harmonized national projects, report. Brussels: ECSI Steering Committee.

Eklöf, J.A. 2000. European customer satisfaction index: Pan-European telecommunication sector report, Based on 1999 pilot studies. Stockholm: European Organization for Quality and European Foundation for Quality Management.

EPSI Rating. 2006. Customer Satisfaction 2005: Pan European Benchmark. Stockholm: EPSI Rating.

Forester, M. 1999. 'Deja vu discussion delivers message emphasizing value', Chain Store Age, 75(4): 12.

Fornell, C. \& Bookstein, F. 1982. 'A comparative analysis of two structural equation models: LISREL and PLS applied to market data'. In Fornell, C. (Ed.). A second generation of multivariate analysis. New York: Praeger.

Fornell, C. 1992. 'A national customer satisfaction barometer: The Swedish experience', Journal of Marketing, 55(1): 1-21.

Fornell, C., Johnson, M.D., Anderson, E.W., Cha, J. \& Bryant, B.E. 1996. 'The American customer satisfaction index: Nature, purpose, and findings', Journal of Marketing, 60(4): 7-18.

Fornell, C., Mithas, S., Morgenson, F.V. III \& Krishnan, M.S. 2006. 'Customer satisfaction and stock prices: High return, low risk’, Journal of Marketing, 70(1): 3-14.

Forza, C. \& Filippini, R. 1998. 'TQM impact on quality conformance and customer satisfaction: A causal model', International Journal of Production Economics, 55(1):1-20.

Gallarza, M.G. \& Saura, I.G. 2006. 'Value dimensions, perceived value, satisfaction and loyalty: An investigation of university student's travel behaviour', Tourism Management, 27(3): 437-452.

Green, S. \& Boshoff, C. 2002. 'An empirical assessment of the relationships between service quality, satisfaction and value: A tourism study', Management Dynamics: Contemporary Research, 11(3): 2-16.

Grönroos, C. 1984. 'An applied service marketing theory', European Journal of marketing, 18(4): 36-44.
Grönroos, C. 1990. Services management and marketing: Managing the moments of truth in service competition. Lexington, M.A.: Lexington Books.

Hackl, P., Scharitzer, D. \& Zuba, R. 2000. 'Customer satisfaction in the Austrian food retail market', Total Quality Management, 11(7):S999-S1006.

Hardie, N. 1998. 'The effects of quality on business performance’, Quality Management Journal, 5(3): 65-83.

Hart, C.W. \& Johnson, M.D. 1999. 'Growing the trust relationship’, Marketing Management, Spring: 8-19.

Hart, C.W. L., Heskett, J.L \& Sasser, W.E. (Jr.). 1990. 'The profitable art of service recovery', Harvard Business Review, 68(4): 148-156.

Heskett, J.L. 2002. 'Beyond customer loyalty', Managing Service Quality, 12(6): 355-357.

Heskett, J.L., Sasser, W.E. (Jr) \& Schlesinger, L.A. 1997. The service profit chain. How leading companies link profit and growth to loyalty, satisfaction and value. New York: The Free Press.

Iniesta, M.A. \& Sánchez, M. 2002. 'Retail-consumer commitment and market segmentation', The International Review of Retail, Distribution and Consumer Research, 12(3): 261-279.

Jensen, H.R. 1996. 'The interrelationship between customer and consumer value', Asia Pacific Advances in Consumer Research, 2: 60-63.

Johnson, M.D. \& Ettlie, J.E. 2001. 'Technology, customization, and reliability', Journal of Quality Management, 6(2): 193-210.

Johnson, M.D. \& Fornell, C. 1991. 'A framework for comparing customer satisfaction across individuals and product categories', Journal of Economic Psychology, 12(2): 267-286.

Johnson, M.D. 2003. Personal communication.

Johnson, M.D. \& Nilsson, L. 2000. The impact of reliability and customization on customer satisfaction for goods versus services. Ann Arbor, MI: University of Michigan Business School (Working Paper No. 00-027).

Johnson, M.D., Anderson, E.W. \& Fornell, C. 1995. 'Rational and adaptive performance expectations in a customer satisfaction framework', Journal of Consumer Research, 21(4):695-707.

Johnson, M.D., Gustafsson, A., Andreassen, T.W., Lervik, L. \& Cha, J. 2001. 'The evaluation and future of national customer satisfaction index models', Journal of Economic Psychology, 22(2): 217-245.

Johnson, M.D., Nader. G. \& Fornell, C. 1996. 'Expectations, perceived performance, and customer 
satisfaction for a complex service, the case of bank loans', Journal of Economic Psychology, 17(2): 163-182.

Juhl, H.J., Kristensen, K. \& Østergaard, P. 2002. 'Customer satisfaction in European food retailing', Journal of Retailing and Consumer Services, 9(6): 327-334.

Kumar, A. \& Grisaffe, D.B. 2004. 'Effects of extrinsic attributes on perceived quality, customer value, and behavioral intentions in B2B settings: A comparison across goods and service industries', Journal of Business-toBusiness Marketing, 11(4): 43-74.

Lai, A.W. 1995. 'Consumer values, product benefits and customer value: a consumption behavior approach', Advances in Consumer Research, 22(1): 381-388.

Lin, C-H., Sher, P.J. \& Shih, H-Y. 2005. 'Past progress and future directions in conceptualising customer perceived value', International Journal of Service Industry Management, 16(4): 318-336.

Liu, C-M. 2005. 'The multidimensional and hierarchical structure of perceived quality and customer satisfaction', International Journal of Management, 22(3): 426-435.

Mackay, H. 1999. Turning point: Australians choosing their future. Sydney: MacMillan.

Mannering, F. \& Winston, C. 1991. 'Brand loyalty and the decline of American automobile firms', Brookings Papers on Economic Activity, 67-114.

Martensen, A., Grønholdt, L. \& Kristensen, K. 2000. 'The drivers of customer satisfaction and loyalty, cross industry findings from Denmark', Total Quality Management, 11(4/5/6): S544-S553.

Mittal, B. \& Lassar, W.M. 1998. 'Why do customers switch? The dynamics of satisfaction versus loyalty', The Journal of Services Marketing, 12(3): 177-194.

Nilson, T.H. 1992. Value-added marketing: Marketing management for superior results. Berkshire: McGraw-Hill.

Oliver, R.L. 1999. 'Whence consumer loyalty?', Journal of Marketing, 63(4): 33-44.

Olsen, L.V. \& Johnson, M.D. 2003. 'Service equity, satisfaction, and loyalty: From transaction specific to cumulative evaluations', Journal of Service Research, 5(3): 184-195.

Ostrom, A. \& Iacobucci, D. 1995. 'Consumer trade-offs and the evaluation of services', Journal of Marketing, 59(1): 1728.

Pitt, L.F. \& Jeantrout, B. 1994. 'Management of customer expectations in service firms: A study and a checklist', The Services Industries Journal, 14(2): 170-189.

Pitt, L.F., Oosthuizen. P. \& Morris, M.H. 1992. 'Service quality in a high-tech industrial market: An application of
SERVQUAL'. In Leone, R.P. \& Kumar, V. (Eds.). American Marketing Association educators' proceedings: Enhancing knowledge development in marketing. Chicago: American Marketing Association, p.p. 46-53.

Rangaswamy, A., Burke R. R. \& Oliva, T. A. 1993. 'Brand equity and the extendibility of brand names’, International Journal of Research in Marketing, 10(1): 61-75.

Robledo, M.A. 2001. 'Measuring and managing service quality: integrating customer expectations', Managing Service Quality, 11(1): 22-31.

Sousa, R. \& Voss, C.A. 2002. 'Quality management revisited: A reflective review and agenda for future research', Journal of Operations Management, 20(1): 91109.

Steenkamp, J-B.E.M. \& Van Trijp, H.C.M. 1996. 'Quality guidance: A Consumer-based approach to food quality improvement using partial least squares', European Review of Agricultural Economics, 23(2): 195-215.

Sweeney, J.C. \& Soutar, G.N. 2001. 'Consumer perceived value: The development of a multiple item scale', Journal of Retailing, 77(2): 203-220.

Teboul, J. 1991. Managing quality dynamics. London: Prentice Hall.

Terblanche, N.S. 2006. 'The relationship between customer satisfaction and loyalty: An application of the American Customer Satisfaction Index in the South African fast food industry'. In press, Management Dynamics: Contemporary Research.

Treadgold, A. 1999. 'The outlook for Asian retailing', Discount Merchandiser, 39(5): 45-46.

Webster, C. 1989. 'Can consumers be segmented on their basis of service quality expectations', Journal of Services Marketing, 3(2): 35-53.

Wetzels, M., De Ruyter, K. \& Van Birgelen, M. 1998. 'Marketing service relationships: the role of commitment', Journal of Business \& Industrial Marketing, 13(4/5): 406423.

Wold, H. 1982. 'Systems under direct observation using PLS'. In Fornell, C. (Ed.). A second generation of multivariate analysis: Methods. Praeger, New York.

Woodruff, B.R. \& Gardial, F.S. 1996. Know your customer: New approaches to understanding customer value and satisfaction. Malden: Blackwell Business.

Woodruff, R.B. 1997. 'Customer value: The next source for competitive advantage', Journal of the Academy of Marketing Science, 25(2): 139-153.

Yu, L. 2005. 'The great expectations effect', MIT Sloan Management Review, 47(1): 5. 
Zeithaml V.A., Berry, L.L. \& Parasuraman, A. 1996. 'The behavioural consequences of service quality', Journal of Marketing, 60 (2): 31-46.

Zeithaml V.A., Parasuraman, A. \& Berry, L.L. 1990. 'Guidelines for conducting service quality research', Marketing Research, 2(4): 34-44.

Zeithaml, V.A. \& Bitner, M.J. 1996. Services marketing. New York: McGraw-Hill.

Zeithaml, V.A. 1988. 'Consumer perceptions of price, quality, and value: a means-end model and synthesis of evidence', Journal of Marketing, 52(3): 2-22.

Zeithaml, V.A., Berry, L.L. \& Parasuraman, A. 1993. 'The nature and determinants of customer expectations of service', Journal of the Academy of Marketing Science, 21(1): 1-12. 